\title{
The practice of physical exercise in the cardiovascular and psychobiological health of university students
}

\author{
A prática de exercício físico na saúde cardiovascular e psicobiológica de universitários \\ La práctica del ejercicio físico en la salud cardiovascular y psicobiológica de estudiantes \\ universitários
}

Received: 12/21/2021 | Reviewed: 12/29/2021 | Accept: 01/05/2022 | Published: 01/08/2022

Carini Silva da Silva
ORCID: https://orcid.org/0000-0003-1131-2205
Federal University of Goias, Brazil
E-mail:carinisilvadasilva @ gmail.com
Gabriela de Oliveira Teles
ORCID: https://orcid.org/0000-0003-2718-1705
Federal University of Goias, Brazil
E-mail: gabrielaef.ufg @ hotmail.com
Vitor Alves Marques
ORCID: https://orcid.org/0000-0002-3194-9118
Federal University of Goias, Brazil
E-mail: vitor_alvesmarques@ hotmail.com
Maria Sebastiana Silva
ORCID: https://orcid.org/0000-0001-7265-5872
Federal University of Goias, Brazil
E-mail: mssilva@ ufg.br
Ana Cristina Silva Rebelo
ORCID: https://orcid.org/0000-0002-9214-5025
Federal University of Goias, Brazil
E-mail: anacristina.silvarebelo@gmail.com
Tatiana de Sousa Fiuza
ORCID: https://orcid.org/0000-0003-0135-177X
Federal University of Goias, Brazil
E-mail: tatianaanatomia @gmail.com

\begin{abstract}
This study evaluated the effects of physical exercise on cardiovascular and psychobiological health (levels of anxiety, depression, fatigue) in university students. A cross-sectional study was conducted, including 72 students in the health care field in 2018. First, an anamnesis was conducted, with information on the eligibility criteria and the physical exercise they practice, to obtain the groups "practices physical exercise" and "no physical exercise." Among eligible individuals, anthropometric measurements were taken, heart rate variability was recorded, questionnaires on depression, anxiety, fatigue, and physical activity were applied, along with a cardiorespiratory test. Of the student participants, $45.0 \%$ were female, $20.0 \%$ were male, and 42 reported exercising, 30 did not. High levels of depression, anxiety, fatigue, and body fat percentage above adequate levels were observed in the study group. Students who practiced physical exercise had lower depression scores, lower body fat percentage, and better autonomic modulation when comparing study groups. There was no difference in cardiorespiratory fitness between practitioners and non-practitioners of physical exercise. A more active lifestyle, including the practice of regular physical activity, is a practical component in improving cardiometabolic and psychobiological profiles in university students and, therefore, should be encouraged during university life.
\end{abstract}

Keywords: Physical activity; Obesity; Mental health; Sedentary lifestyle.

\section{Resumo}

O objetivo do presente estudo foi avaliar a prática de exercício físico na saúde cardiovascular e psicobiológica (níveis de ansiedade, depressão, fadiga) de universitários. Para isso, realizou-se um estudo transversal com 72 estudantes da área da saúde em 2018. Os participantes foram submetidos a uma anamnese com informações dos critérios e elegibilidade e da prática de exercícios físicos para obtenção dos grupos "pratica exercícios físicos" e "não pratica exercícios físicos". Nos elegíveis foram realizadas as medidas antropométricas, registro da VFC, aplicação dos questionários de depressão, ansiedade, fadiga e de atividade física, além da realização do teste cardiorrespiratório. Do total de estudantes $45,0 \%$ eram do sexo feminino e 20,0\% masculino, e 42 deles informaram realizar exercícios físicos e 30 não. Considerando o total de estudantes foi observado altos níveis de depressão, ansiedade, fadiga e percentual de gordura corporal acima do adequado. Na comparação entre grupos de estudos, identificou-se que os estudantes que 
praticavam exercício físico possuíam menores escores de depressão, percentual de gordura corporal mais baixos, e melhor modulação autonômica. Não houve diferença na aptidão cardiorrespiratória entre os que praticantes e não praticantes de exercício físico. A adoção de um estilo de vida mais ativo, através da prática da atividade física regular, tem se mostrado um fator eficaz componentes na melhora do perfil cardiometabólico e psicobiológico em universitários, devendo, por isso, ser estimulada também durante a vida universitária.

Palavras-chave: Atividade física; Obesidade; Saúde mental; Sedentarismo.

\section{Resumen}

El objetivo del presente estudio fue evaluar la práctica de ejercicio físico en la salud cardiovascular y psicobiológica (niveles de ansiedad, depresión, fatiga) de estudiantes universitarios. Para ello, se realizó un estudio transversal con 72 estudiantes del área de la salud en 2018. Los participantes fueron sometidos a una anamnesis con información sobre los criterios y elegibilidad y sobre la práctica de ejercicio físico para obtener los grupos "hace ejercicio físico". "y" no practica ejercicios físicos ". En los individuos elegibles se tomaron medidas antropométricas, se registró la VFC, se aplicaron cuestionarios sobre depresión, ansiedad, fatiga y actividad física, además de la prueba cardiorrespiratoria. Del total de estudiantes, el $45.0 \%$ eran mujeres y el $20.0 \%$ hombres, y 42 de ellos reportaron hacer ejercicio y 30 no. Considerando el total de estudiantes, se observaron altos niveles de depresión, ansiedad, fatiga y porcentaje de grasa corporal por encima del nivel adecuado. Al comparar los grupos de estudio, se identificó que los estudiantes que practicaban ejercicio físico tenían menores puntuaciones de depresión, menor porcentaje de grasa corporal y mejor modulación autonómica. No hubo diferencias en la aptitud cardiorrespiratoria entre los practicantes y no practicantes de ejercicio físico. La adopción de un estilo de vida más activo, a través de la práctica de actividad física regular, ha demostrado ser un componente eficaz en la mejora del perfil cardiometabólico y psicobiológico en los estudiantes universitarios y, por tanto, también debe fomentarse durante la vida universitaria.

Palabras clave: Actividad física; Obesidad; Salud mental; Estilo de vida sedentário.

\section{Introduction}

In recent decades, the incidence of cardiovascular disease has increased among young people due to an increase in sedentary lifestyle, obesity, inadequate nutrition, and excessive alcohol consumption, which contributed to high levels of blood glucose and cholesterol, which are known to be risk factors for cardiovascular disease (Andersson \& Vasan, 2018). For example, a study that evaluated the prevalence of risk factors for cardiovascular disease in 1,123 young people with a mean age of 26 years observed that $44.2 \%$ consumed alcohol in excess, $38.2 \%$ were physically inactive, $21.9 \%$ consumed high amounts of fat, and $24.3 \%$ had two or more of these risk factors, increasing the chances of developing cardiovascular disease (Paulitsch et al., 2017).

Although genetics have a significant influence on the development of chronic non-communicable diseases, lifestyle can further influence the development of these diseases. For example, a study carried out with 130 students with a mean age of 22 showed that $29.2 \%$ had pre-hypertension. In addition, high blood pressure values are associated with higher body mass index (BMI), reiterating the importance of adopting a healthy lifestyle since youth (AlWabel et al., 2018).

Nationally, $26.8 \%$ of Brazilians over 20 years are obese, and $61.7 \%$ are overweight. Among adolescents aged 15 to 17 years, overweight reaches 19.4\% (IBGE, 2020). According to Gaviria et al. (2017), among the population of young university students in the health care field, the prevalence of obesity and overweight is $7.6 \%$ and $25.1 \%$, respectively. One of the leading causes of excess weight is a sedentary lifestyle and lack of physical activity. The National Health Survey (2019) identified that $40.3 \%$ of people are physically inactive in Brazil.

An increased sedentary lifestyle is associated with impairments in cardiorespiratory fitness (CRF), the autonomic nervous system (ANS), and mental health. In addition, a sedentary lifestyle increases the chances of developing diseases such as high blood pressure, diabetes, cancer, in addition to increasing mortality (Arocha Rodulfo, 2019; Ozemek et al., 2018; Silva et al., 2021; Tremblay et al., 2017; WHO, 2017). Among the factors that most prevent young people from practicing physical exercise are excess body weight, long periods of studying ( $>7$ hours), and the presence of musculoskeletal injuries (ConchaCisternas et al., 2018).

The functioning of the ANS can be evaluated through the analysis of HRV that can be performed using linear methods, such as time-domain or frequency-domain analysis and non-linear methods. (Marães, 2010; Task Force, 1996). This tool is vital 
for the early diagnosis of some diseases. For example, according to Hillebrand et al. (2013), low HRV values are associated with a $32-45 \%$ higher cardiovascular event risk.

Cardiorespiratory fitness (CRF) is another significant health marker, a predictor of cardiovascular events and all-cause mortality, regardless of sex, age, race, or health status. According to a report published by the American Heart Association (2014), cardiovascular disease is responsible for a third of deaths worldwide. Individuals with moderate to high CRF have a significantly reduced risk of mortality or developing cardiovascular disease (Mandsager et al., 2018; Ozemek et al., 2018).

In addition to the damage to cardiometabolic health in young university students, it is also possible to identify a worsening in the mental health of these individuals, with an increase in depression, anxiety, and fatigue, promoting a decrease in quality of life. Quality of life is a complex condition that involves psychobiological (WHO, 2017) and physical (Ware \& Sherbouerne, 1992) factors. According to the WHO, depression affects around 322 million people worldwide, the prevalence being higher in the female population. In Brazil, depression affects 11.5 million people, equivalent to $5.8 \%$ of the population (WHO, 2017). In addition, some social groups are more susceptible to developing this disease, such as university students. In Brazil, seven out of ten students at federal institutions suffer from depression, anxiety or stress (Fórum Nacional de Pró-reitores de Assuntos Estudantis, 2016).

Students may be more vulnerable to depression due to several factors, including changes in lifestyle in early adulthood, academic concerns, sleep and eating disorders, financial problems, and changes in family relationships. In this population, the prevalence of depression is higher than in the general population, as shown by a systematic review by Ibrahim et al. (2013), in which $30.6 \%$ of students in the United States have depression, while in the general population, this disease affects 9\%. According to the WHO (2017), Brazil has the highest prevalence of anxiety, reaching 9.3\%, and in university students, it reaches $33.8 \%$ (Quek et al., 2019). Furthermore, studies carried out by Amaducci et al. (2010) found that college students without any comorbidities had high levels of fatigue, affecting their ability to perform daily activities.

Physical exercise influences all cardiometabolic and psychobiological factors mentioned. Therefore, the present study aimed to evaluate the practice of physical exercise in the cardiovascular (body composition, HRV, and CRF) and psychobiological (levels of anxiety, depression, fatigue) health of university students.

\section{Methodology}

This cross-sectional study consisted of a quantitative laboratory research (Ferrati, 1982) was approved by the Ethics Committee of the Federal University of Goiás, decision n ${ }^{\circ} .2 .615 .302$ and conducted following the standards of conduct in research with human beings (CNS Resolution 466/12). All volunteers included in the study signed an informed consent form to participate.

Newly enrolled students at the Federal University of Goiás of both genders, aged over 18 years, in the 2018 school year were included. Those who had frequent arrhythmias and extrasystoles at rest or triggered during exercise testing, hypertension above stage 1 (systolic blood pressure greater than $140 \mathrm{mmHg}$ and diastolic blood pressure greater than $90 \mathrm{mmHg}$ ); obstructive pulmonary disease; type 1 diabetes mellitus; neoplasm; renal insufficiency; sequelae of stroke, osteoarticular alterations, or who used psychotherapeutics were excluded.

Students who had just entered the university were recruited through social networks, and 72 students responded to the invitation. First, an anamnesis was conducted to identify the participants' gender, age, tobacco use, use of medication or food supplements, physical exercise, and date of last menstruation (in the case of women). Then, based on systematic and regular physical exercise practice data, the students were divided into "practice physical exercise" and "no physical exercise." 
The selected participants were brought to the assessments in two visits. In the first, they received an anthropometric assessment and HRV recording and answered the depression, anxiety, fatigue, and physical activity questionnaires. They performed the cardiorespiratory fitness (CRF) test in the second visit.

\section{Body composition assessment}

Body mass index (BMI) and body fat percentage were used to assess body composition. BMI was calculated by the ratio of body mass $(\mathrm{BM})$ in kilograms, and the square of height $(\mathrm{H})$, in meters. BM was measured on a digital anthropometric scale (Toledo, São Paulo, Brazil) and H on a portable stadiometer (Sanny, São Paulo, Brazil). Body fat percentage was estimated based on body density (BD) and Siri's (1961) equation. The BD was calculated from mathematical models developed by Jackson and Pollock (1978) for men and Jackson et al. (1980) for women, from the skinfold measurements (mm) obtained in a scientific adipometer, Cescorf brand, with an accuracy of $1 \mathrm{~mm}$.

\section{Depression Questionnaire}

A Beck Depression Inventory (BDI) questionnaire was applied (Beck et al., 1961), validated for Portuguese by Gorestein \& Andrande (1998), to assess the level of depression. The BDI is a structured instrument composed of 21 categories of symptoms and attitudes, which describe affective and somatic cognitive-behavioral manifestations of depression. The score ranges from 0 to 63 , and there are several classifications, in which scores up to 9 points mean no depression; 10 to 18 points, mild to moderate depression; from 19 to 29 points, moderate to severe depression; and from 30 to 63 points, severe depression.

\section{Anxiety Questionnaire}

The State-Trait Anxiety Inventory (STAI), which quantifies subjective components related to anxiety, was developed by Spielberger et al. (1970) and was translated and adapted for Brazil by Biaggio et al. (1977), assessed anxiety levels. The STAI contains scales that assess anxiety as a state (STAI-S) and anxiety as a trait (STAI-T). State anxiety concerns a transitory reaction directly related to an adverse situation that presents itself in a given moment. On the other hand, state anxiety refers to a more stable aspect related to the individual's propensity to deal with greater or lesser anxiety throughout their life.

\section{Fatigue Questinonaire}

Fatigue level was assessed using the Piper Fatigue Scale (Mota et al., 2009), which contains 22 items distributed in four dimensions: behavioral aspects related to functional capacity, including personal issues, social activities, and sexual relations; affective; sensory/psychological, including self-perception; and emotional and cognitive components in the presence of fatigue. Each dimension and the total score received a score scaled from 0-10. This score corresponds to the average of the scores for each item. The cutoff point for fatigue was four (score equal to or less than four, without fatigue; more than four, with fatigue).

In this scale, in addition to the 22 scored items, five open questions not used in scoring allow for additional data such as the duration of fatigue, what the individual believes causes fatigue, and the presence of other symptoms, enriching the quality of information. The composition of this scale with multiple dimensions is an important feature, as it allows recognizing the expression of fatigue in the individual's life (Mota et al., 2009).

\section{Physical Activity Questionnaire}

Physical activity level was assessed using the Habitual Physical Activity Questionnaire, used to classify the groups of sedentary and physically active participants. It consists of 16 questions covering three Habitual Physical Activity (HFA) scores in the last 12 months: 1 - Occupational Physical Activity (OFA) score with eight questions; 2 - Physical Exercises in Leisure 
(PEL) score with four questions; and 3 - Leisure and Locomotion Activities (LLA) score, with four questions (Baecke et al., 1982). The total score is the sum of all previous scores, indicating the level of physical activity.

\section{Heart rate variability}

HRV was recorded to assess cardiovascular autonomic control at rest in the supine position for six minutes. Beats were collected using a Polar® model v800cx frequency meter (Electro Oi, Finland). Data were collected from a belt with a coded transmitter, placed in the chest region, at the height of the fifth intercostal space, and later transferred through an interface to a compatible computer and analyzed using the Kubios 3.0 software.

For the HRV analyses, the stretches with the highest signal stability were selected, including at least 256 consecutive beats (Task Force, 1996). In addition, volunteers were instructed to abstain from alcohol and stimulants for at least 12 hours before the test, to avoid strenuous exercise, and to have a period of regular and good quality sleep on the night before data collection (Minatel et al., 2012; Zuttin et al., 2008). Volunteers who did not follow these guidelines were excluded from the analysis, leaving 54 individuals.

\section{Cardiorespiratory Fitness Test}

The incremental ergospirometric test protocol assessed CRF (O. B. e Silva, 2014) with no incline. The test used a motorized treadmill (ATL, Inbramed, Brazil) coupled to a gas analyzer (Cortex, Metalyzer II, Rome, Italy) and a laptop computer. Participants remained at rest in an orthostatic position for 3 minutes pre-exercise, followed by a 2-minute warm-up at $5 \mathrm{~km} / \mathrm{h}$. After that, speed was increased by $1 \mathrm{~km} / \mathrm{h}$ every minute until exhaustion. After exhaustion, active recovery was performed for 2 minutes at $2 \mathrm{~km} / \mathrm{h}$, and the participant remained seated for 4 minutes. The criteria used for test interruption were: (1) the participant's inability to perform the exercise; (2) marked increase in systolic blood pressure (reaching values greater than $200 \mathrm{mmHg}$ ); (3) reaching the maximum HR predicted for the age; or (4) respiratory exchange ratio > 1.15.

Heart rate was continuously monitored using an HR monitor (Polar V800, Finland). In addition, exhaled air was measured continuously, breath by breath, on the gas analyzer to determine VO2 peak, representing the highest 10-second mean VO2 value, with inclusion criteria consistent with conventional guidelines for VO2 peak (Guazzi et al., 2012). This test was performed on the second visit of the study, and 17 individuals were present.

\section{Statistical Analysis}

The Statistical Package for Social Sciences (SPSS - Armonk, NY: IBM Corp), version 22.0, was used for statistical analysis. First, the Kolmogorov-Smirnov test was performed to verify the normality of the data. Next, the sample was separated into two groups to assess the influence of physical exercise: those who practice and those who do not practice physical exercise. Finally, the comparison of parametric variables between groups was performed using Student's t-test for independent samples, and the Mann-Whitney test was used for non-parametric variables. Data are presented in mean and standard deviation and absolute numbers and frequencies.

\section{Results and Discussion}

The study participants $(\mathrm{n}=72)$ were aged $19.57 \pm 2.96$, BMI $22.67 \pm 4.27 \mathrm{~kg} / \mathrm{m} 2$, body fat percentage of $20.12 \pm 9.16 \%$, and physical activity score of $7.76 \pm 1.19$. Of the study participants, $41.7 \%(\mathrm{n}=30)$ practiced physical exercise, 17 were men and 13 women, and $58.3 \%(n=42)$ did not practice physical exercise (13 men and 29 women). However, similar scores from the habitual physical activity questionnaire were observed $(\mathrm{p}=0.490)$ among no-exercise participants $(7.22 \pm 0.98)$ and those who 
practiced physical exercise $(8.51 \pm 1.05)$, with the majority (94.4\%) being active and only $5.6 \%$ sedentary. In addition, it was found that the practice of physical exercise was higher among men than among women $(p=0.030)$.

Physical activity is characterized as any bodily activity that expends more energy than at rest, while physical exercise is a planned, systematized, and targeted physical activity (Caspersen et al., 1985). Studies have shown that active people from different populations are more physically fit. They have lower body fat and higher flexibility, strength, and muscle endurance compared to sedentary and less active people (Marker et al., 2018; Silva et al., 2019). In addition, regular physical exercise has additional health benefits such as improved blood glucose, lipid profile, cardiorespiratory fitness, and mental health, in addition to increased life expectancy (Kiviniemi et al., 2014; Maillard et al., 2018; Stavrinou et al., 2018; Viana et al., 2019).

One in four adults and four in five adolescents do not perform enough physical activity (WHO, 2020). The population of young university students in the first semesters of undergraduate is more likely to adopt an unhealthy lifestyle with a reduction in physical exercise and an increase in time spent doing sedentary behaviors. This decline is due to the high student and professional demand and the sudden transition from teenage life to adulthood, promoting less time available for physical exercise caused by the increase in daily activities (Bhatti et al., 2020).

As for the body composition assessment (Table 1), the BMI results showed that $22.2 \%$ of participants were overweight or obese, and $40.2 \%$ had a moderately high or high percentage of fat.

The comparison results between the groups showed lower body fat among those who practiced physical exercise ( $\mathrm{p}=0.007$ ), which corroborates the reports of Mondal and Mishra (2017), who claim that body fat and physical exercise are inversely related. However, it was also found in the present study that, of the total number of university students evaluated, $39.1 \%$ of the females had a percentage of fat classified as moderately high and high, while only $8.3 \%$ of males were included in this classification. This result can be explained by the lower rate of body fat oxidation in women than in men, which contributes to fat storage (Schorr et al., 2018).

Table 1. Student body composition data $(\mathrm{n}=72)$.

\begin{tabular}{|c|c|c|c|c|c|c|c|c|}
\hline \multirow[b]{2}{*}{ Variable } & \multicolumn{3}{|c|}{ Mean \pm SD } & \multirow[b]{2}{*}{$p$} & & \multirow[b]{2}{*}{ Total } & \multicolumn{2}{|c|}{ Classification } \\
\hline & Total & $\begin{array}{c}\text { No physical } \\
\text { exercise }\end{array}$ & $\begin{array}{c}\text { Practiced physical } \\
\text { exercise }\end{array}$ & & & & $\begin{array}{c}\text { No physical } \\
\text { exercise }\end{array}$ & $\begin{array}{c}\text { Practiced physical } \\
\text { exercise }\end{array}$ \\
\hline \multirow{4}{*}{$\begin{array}{l}\mathrm{BMI}^{1} \\
\left(\mathrm{~kg} / \mathrm{m}^{2}\right)\end{array}$} & & \multirow{4}{*}{$22.20 \pm 8.62$} & \multirow{4}{*}{$23.33 \pm 23.33$} & \multirow{4}{*}{0.271} & Underweight & $9(12.5)$ & $6(8.3)$ & $3(4.2)$ \\
\hline & & & & & Eutrophic & $47(65.3)$ & $25(34.8)$ & $18(25.0)$ \\
\hline & & & & & Overweight & $13(18.0)$ & $10(13.8)$ & $7(9.8)$ \\
\hline & & & & & Obese & $3(4.2)$ & $1(1.4)$ & $2(2.7)$ \\
\hline \multirow{7}{*}{$\begin{array}{l}\mathrm{BF}^{2} \\
(\%)\end{array}$} & & \multirow{7}{*}{$22.55 \pm 8.62$} & \multirow{7}{*}{$16.73 \pm 8.93$} & \multirow{7}{*}{0.007} & Very Low & $2(2.8)$ & $1(1.4)$ & $1(1.4)$ \\
\hline & & & & & Excellent & $12(16.6)$ & $5(7.0)$ & $7(9.6)$ \\
\hline & & & & & Very good & $7(9.8)$ & $2(2.8)$ & $5(7.0)$ \\
\hline & & & & & Good & $12(16.6)$ & (8.3) & $6(8.3)$ \\
\hline & & & & & Adequate & $10(14.0)$ & $5(7.0)$ & $5(7.0)$ \\
\hline & & & & & Moderately high & 14 (19.3) & $10(13.8)$ & $4(5.5)$ \\
\hline & & & & & High & 15 (20.9) & $13(18.1)$ & $2(2.8)$ \\
\hline
\end{tabular}

${ }^{1}$ Body Mass Index ${ }^{2}$ Body Fat. Source: Authors.

Excess body fat in college students was related to high fast-food consumption, sedentary lifestyle, and worse CRF and considered a health risk in the short and long term (Harmouche-Karaki et al., 2020; Jiang et al., 2019). In addition, high values of body fat are associated with an increased chance of developing various cardiometabolic diseases (Engin, 2017). 
In a study with a sample of 284 students aged around 19 years, a prevalence of $25.5 \%$ of arterial hypertension was found, and it was associated with obesity, increased waist circumference, and diabetes mellitus. In addition, $70.0 \%$ of students had one or more cardiovascular risk factors (Ignacio et al., 2019).

As for the psychobiological assessment, as shown in Table 2, lower fatigue ( $\mathrm{p}=0.050)$ and depression $(\mathrm{p}=0.019)$ scores were found in students who regularly practice physical exercise. The results of the psychobiological profile categorization indicated that of the total study participants, $91.7 \%$ had medium to severe levels of fatigue, $34.8 \%$ moderate to severe depressive symptoms, $48.6 \%$ high to very high trait anxiety, and $54.2 \%$ high to very high state anxiety (Table 3 ).

Table 2. Scores of psychobiological variables in the total number of students and comparison between groups that do not practice and practice physical exercise (mean values and standard deviation).

\begin{tabular}{lcccc}
\hline Variables & Total & $\begin{array}{c}\text { No physical exercise } \\
(\mathbf{n = 4 2})\end{array}$ & $\begin{array}{c}\text { Practiced physical exercise } \\
(\mathbf{n = 3 0})\end{array}$ & $\boldsymbol{p}^{\mathbf{1}}$ \\
\hline Fatigue & $3.60 \pm 2.02$ & $3.98 \pm 1.86$ & $3.08 \pm 2.16$ & 0.050 \\
Depression & $8.72 \pm 5.81$ & $10.28 \pm 6.22$ & $6.53 \pm 4.41$ & $\mathbf{0 . 0 1 9}$ \\
Trait anxiety & $46.00 \pm 15.12$ & $48.57 \pm 8.97$ & $42.40 \pm 20.56$ & 0.563 \\
State anxiety & $46.54 \pm 14.85$ & $48.90 \pm 9.44$ & $43.33 \pm 19.86$ & 0.837 \\
\hline
\end{tabular}

${ }^{1}$ Mann-Whitney Test; Significance level used: $\mathrm{p}<0.05$. Source: Authors.

In the present study, more than 50\% of the students manifested high fatigue levels, different from Abdali et al. (2019), which was observed in young people of the same age group, 13.8\% with fatigue. Furthermore, the presence of depressive symptoms was found in $34.8 \%$ of the participants, and these data corroborate a study by Tung et al. (2018), which demonstrated that the prevalence of depression in university students is higher than in the general population. Depression is associated with lifestyle components, such as body composition and sedentary behavior. In this sense, there are reports that obese individuals are more likely to develop this disease and that long periods in the sitting position ( 7.96 hours/day) have significant effects on depression, in addition to increasing the occurrence of mortality from 18 to $45 \%$ (Lee \& Kim, 2019). Other factors associated with high rates of depression are inadequate diet, alcohol consumption, and smoking (Ramón-Arbués et al., 2020).

Table 3. Distribution of students according to the categorization of psychobiological variables.

\begin{tabular}{|c|c|c|c|c|}
\hline \multirow{2}{*}{ Variables } & \multirow{2}{*}{ Categorization } & Total $(n=72)$ & No Physical Exercise $(n=42)$ & $\begin{array}{c}\text { Practiced } \\
\text { physical exercise }(n=30)\end{array}$ \\
\hline & & n $(\%)$ & n $(\%)$ & n $(\%)$ \\
\hline \multirow{4}{*}{ Fatigue } & None & $6(8.3)$ & $1(1.4)$ & $5(6.9)$ \\
\hline & Mild & $28(38.9)$ & $15(20.9)$ & $13(18.0)$ \\
\hline & Moderate & $30(41.7)$ & $21(29.2)$ & $9(12.5)$ \\
\hline & Severe & $8(11.1)$ & $5(7.2)$ & $3(3.9)$ \\
\hline \multirow{4}{*}{ Depression } & None & $47(65.3)$ & $23(31.9)$ & $24(33.4)$ \\
\hline & Mild to moderate & $21(29.1)$ & $15(20.8)$ & $6(8.3)$ \\
\hline & Moderate to severe & $4(5.6)$ & $4(5.6)$ & 0 \\
\hline & Low or mild & $11(15.3)$ & $2(2.8)$ & $9(12.5)$ \\
\hline \multirow{3}{*}{ Trait Anxiety } & Moderate & $26(36.1)$ & $21(29.1)$ & $5(7.0)$ \\
\hline & High to severe & $34(47.2)$ & $18(24.9)$ & $16(22.3)$ \\
\hline & Very high & $1(1.4)$ & $1(1.4)$ & 0 \\
\hline \multirow{4}{*}{ State Anxiety } & Low or mild & $10(13.9)$ & $2(2.8)$ & $8(11.1)$ \\
\hline & Moderate & $23(31.9)$ & $19(26.3)$ & $4(5.6)$ \\
\hline & High to severe & $36(50.0)$ & $19(26.4)$ & $17(23.6)$ \\
\hline & Very high & $3(4.2)$ & $2(2.8)$ & $1(1.4)$ \\
\hline
\end{tabular}

Source: Authors. 
The psychobiological profile also influences cardiometabolic factors, as Chaplin et al. (2021) identified that in young people aged up to 24 years, obesity is a risk factor for depression, as it promotes dysregulation of the hypothalamic-pituitaryadrenal axis, insulin resistance, and psychological distress (Osimo et al., 2019). Depression has become a significant public health problem because it reduces people's quality of life and also because it is associated with suicidal behavior, as demonstrated by Lew et al. (2019), being the fourth leading cause of death among people aged 15 to 29 worldwide (WHO, 2021). In addition, studies published in the literature showed a positive association between stress and fatigue. Thus, the higher the stress levels, the higher the fatigue levels (Doerr et al., 2015). According to Beiter et al. (2015), university students have high levels of stress, possibly associated with academic performance, concern with life after graduation, post-graduation, financial and family problems, sleep quality, body image, of self-esteem.

As for anxiety, it was observed that about half of the individuals had high anxiety, both in trait anxiety and in state anxiety, as observed by Lun et al. (2018). In addition, many factors associated with depression in most university students also present from anxiety, such as poor sleep quality, low self-esteem, insufficient levels of physical activity, and high student demand, among others (Younes et al., 2016).

Our results showed that students who practiced physical exercise had lower depression scores $(p \leq 0.01)$ (Table 2), which reaffirms the antidepressant effect of physical exercise both acutely (Meyer et al., 2016) and chronically (Kandola et al., 2019). Furthermore, the chronic effect on depression prevention may be related to exercise-induced CRF improvement, as individuals with low CRF had a 64\% higher risk of developing depression than people with high CRF (Kandola et al., 2019).

Regarding depression treatment, a meta-analysis showed that physical exercise is effective as a non-pharmacological treatment for depression compared to no intervention and when associated with conventional therapies, whether psychotherapy or antidepressant drugs (Kvam et al., 2016).

The practice of physical exercise seems to be necessary for the treatment of this disease and its prevention. For example, a cohort study performed by Harvey et al. (2018), which followed 33,908 adults for 11 years, demonstrated that regular physical exercise was associated with a reduction in the incidence of depression. In addition, physical exercise was able to reduce depressive symptoms, as it induces molecular and cellular changes that contribute to neuroplasticity and promote changes in brain structures, such as the hippocampus, improving self-esteem, increasing and promoting social interactions, and improving physical health (Kandola et al., 2019).

In the present study, anxiety levels were similar between exercisers and non-practitioners, remaining high in both groups. According to Teychenne et al. (2015), individuals who exercise are less anxious than those who do not. However, a systematic review carried out by Stonerock et al. (2015) indicated that physical exercise has a negligible effect on anxiety, demonstrating the need for further studies on the effects of physical exercise in this psychiatric disorder. Furthermore, another study found that long-term physical exercise has a protective effect on depression but not anxiety (Harvey et al., 2018). Physical exercise is known to improve fatigue. However, there are still few studies involving young and healthy populations. (Oberoi et al., 2018).

In order to understand the effect of exercise on some mental health parameters from a holistic perspective, data were collected on anthropometric measurements and the heart rate variability (HRV) of 54 individuals who met the criteria established in the methodology for evaluating HRV was assessed(Table 4). 
Table 4. Heart variability parameters of the total number of students and physical exercise practice. Mean values and standard deviation. $(\mathrm{n}=53)$.

\begin{tabular}{ccccc}
\hline Variable & $\begin{array}{c}\text { Total } \\
(\mathbf{n = 5 3})\end{array}$ & $\begin{array}{c}\text { No physical exercise } \\
(\mathbf{n = 3 4 )}\end{array}$ & $\begin{array}{c}\text { Practice physical } \\
\text { exercise }(\mathbf{n = 2 0})\end{array}$ & $\boldsymbol{p}$ \\
\hline Mean RR & $725.06 \pm 97.28$ & $719.59 \pm 84.54$ & $734.37 \pm 117.64$ & 0.824 \\
SDNN & $36.84 \pm 15.43$ & $34.72 \pm 14.36$ & $40.44 \pm 16.86$ & 0.173 \\
HR average & $84.21 \pm 10.97$ & $84.47 \pm 9.60$ & $83.77 \pm 13.24$ & 0.594 \\
RMSSD & $32.66 \pm 25.64$ & $30.94 \pm 28.14$ & $35.57 \pm 21.08$ & 0.263 \\
NN50 & $28.49 \pm 35.40$ & $23.89 \pm 36.50$ & $36.32 \pm 32.85$ & 0.072 \\
LF & $549.64 \pm 910.03$ & $334.83 \pm 470.13$ & $914.81 \pm 1305.10$ & $\mathbf{0 . 0 2 1}$ \\
HF & $437.68 \pm 873.07$ & $351.15 \pm 876.54$ & $584.78 \pm 869.28$ & $\mathbf{0 . 0 2 5}$ \\
LF/HF & $11.31 \pm 11.01$ & $13.77 \pm 11.45$ & $7.14 \pm 9.32$ & $\mathbf{0 . 0 4 9}$ \\
SD1 & $33.54 \pm 15.17$ & $36.22 \pm 16.13$ & $28.99 \pm 12.48$ & 0.091 \\
SD2 & $26.27 \pm 30.18$ & $17.14 \pm 25.63$ & $41.79 \pm 31.59$ & $\mathbf{0 . 0 0 4}$ \\
Approximate entropy & $1.31 \pm 0.39$ & $1.41 \pm 0.37$ & $1.15 \pm 0.37$ & $\mathbf{0 . 0 1 4}$ \\
Sample entropy & $1.32 \pm 0.38$ & $1.34 \pm 0.41$ & $1.30 \pm 0.33$ & 0.721 \\
\hline
\end{tabular}

Mean RR: Mean of RR intervals; Average HR: average heart rate; SDNN: standard deviation of the mean of all adjacent normal RR intervals; RMSSD: root mean square of successive differences between adjacent normal RR intervals; NN50: Number of pairs of adjacent RR intervals that differ by more than $50 \mathrm{~ms}$ across the recording; LF: low frequency; HF: high frequency; LF/HF: the ratio between LF and HF; SD1: standard deviation of the instantaneous beat-to-beat variability; SD2: long-term standard deviation of continuous RR intervals; Approximate entropy: detects changes in an experimental time series and provides a non-negative number for the series; Sample entropy: the measure of existing disorder in the time series; ${ }^{1}$ Mann-Whitney Test; ${ }^{2}$ T-test of independent samples; a significance level of $<0.05$ was used. Source: Authors.

The assessment of cardiac autonomic modulation showed a significant difference in LF, HF, LF/HF, SD2, and approximate entropy between practitioners and non-practitioners of physical exercise (Table 4). LF is used as a sympathetic modulation index, HF as vagal modulation, and LF/HF ratio as a vagal sympathetic balance (Task Force, 1996). The variables LF, HF, and LF/HF indicated a better sympathovagal balance in the physical exercise group. The low LF/HF values among students who practice physical exercise indicated less sympathetic stimulation and, therefore, the cardioprotective effect of physical exercise (Molina et al., 2016) and the approximate entropy related to the greater complexity and unpredictability of HRV, which reflects a protective cardiovascular effect (Singh et al., 2019). Thus, the present findings demonstrate the importance of exercise for cardiac autonomic regulation. Furthermore, Tornberg et al. (2019) found a positive relationship between HRV and physical exercise, in which individuals who exercise at moderate to vigorous intensity have higher RMSSD values, which indicates more significant parasympathetic activity. Regardless of BMI, waist circumference, or body fat percentage values, these results were identified.

The practice of physical exercise promotes improvement in HRV, increasing vagal tone and decreasing cardiac sympathetic modulation (Kingsley \& Figueroa, 2016). Moraes et al. (2019) evaluated the HRV in 55 young people separated into 4 groups: sedentary, insufficiently active, active, and very active. It was found that the sedentary group had lower mean IRR and RMSSD when compared to the other groups, indicating losses in parasympathetic activity.

A study that analyzed the HRV in physically inactive young people and young people who used bicycles for daily transport found better rates of NN50, RMSSD, and LF for the group that used bicycles as transport (Bueno et al., 2017). The differences found between the present study's RMSSD and LF results and those reported by Bueno et al. (2017) can be justified by the similarity in the level of physical activity in the groups, even though one group practiced physical exercise and the other did not.

Subsequently, 17 individuals performed the CRF test (Table 5), and no significant differences were observed between the groups. 
Table 5. Comparison of cardiorespiratory variables between groups.

\begin{tabular}{cccc}
\hline Variables & $\begin{array}{c}\text { No physical exercise } \\
(\mathbf{n = 9})\end{array}$ & $\begin{array}{c}\text { Practice physical exercise } \\
(\mathbf{n = 8})\end{array}$ & $\boldsymbol{p}$ \\
\hline $\mathrm{PV}^{1}$ & $67.34 \pm 19.54$ & $76.02 \pm 24.73$ & 0.432 \\
\hline $\mathrm{RER}^{1}$ & $1.03 \pm 0.045$ & $1.04 \pm 0.52$ & 0.881 \\
\hline $\mathrm{VO}_{2}(\mathrm{~mL} / \mathrm{kg} \cdot \mathrm{min})^{2}$ & $31.88 \pm 7.07$ & $34.87 \pm 7.19$ & 0.311 \\
\hline $\mathrm{METs}^{2}$ & $9.10 \pm 2.01$ & $9.97 \pm 1.99$ & 0.290 \\
\hline
\end{tabular}

PV: pulmonary ventilation; RER: respiratory exchange ratio; $\mathrm{VO}_{2}$ : oxygen consumption; METs: metabolic equivalents; ${ }^{1}$ T-test of independent samples; ${ }^{2} \mathrm{Mann}$ Whitney Test; a significance level of $<0.05$ was used; $\mathrm{mL} / \mathrm{kg} \cdot \mathrm{min}$ : milliliters per kilogram per minute. Source: Authors.

The CRF analysis showed no difference between individuals who exercised and those who did not. This similarity seems to be associated with their individual physical activity levels, as most participants in both groups were classified as active. However, physical exercise practitioners have higher VO $2_{\max }$ values (Ozemek et al., 2018). Therefore, regular physical exercise and increased CRF for this population are essential for reducing risk factors for cardiovascular disease, improving mental health and academic performance. (Fan, et al., 2020; Marques, et al., 2018).

\section{Conclusion}

The evaluated students had high levels of depression, anxiety, and fatigue. More than half reported not exercising, although they are classified as active, and high body fat was found in a significant amount of them. Exercising was considered an essential factor for reducing depression and body fat and favoring better cardiac autonomic modulation, but it did not influence the students' CRF. A more active lifestyle, including regular physical activity, is a demonstrably effective component in improving university students' cardiometabolic and psychobiological profiles and, therefore, should be encouraged during university life. For future research, it is important to include ways in universities to increase the practice of physical exercise among students, to improve cardiovascular and psychobiological health of students. In addition, verifying which training protocols have greater adherence in this population

\section{References}

Abdali, N., Nobahar, M., \& Ghorbani, R. (2019). Evaluation of emotional intelligence, sleep quality, and fatigue among Iranian medical, nursing, and paramedical students: A cross-sectional study. Qatar Medical Journal, 2019(3), 1-11. https://doi.org/10.5339/qmj.2019.15

AlWabel, A. H., Almufadhi, M. A., Alayed, F. M., Aloraini, A. Y., Alobaysi, H. M., \& Alalwi, R. M. (2018). Assessment of hypertension and its associated risk factors among medical students in Qassim University. Saudi Journal of Kidney Diseases and Transplantation : An Official Publication of the Saudi Center for Organ Transplantation, Saudi Arabia, 29(5), 1100-1108. https://doi.org/10.4103/1319-2442.243959

American Heart Association. (2014). Heart Disease and Stroke Statistics-2014 Update: a Report From the American Heart Association. In Journal of Consumer Health On the Internet (Vol. 18, Issue 2). https://doi.org/10.1080/15398285.2014.902284

Andersson, C., \& Vasan, R. S. (2018). Epidemiology of cardiovascular disease in young individuals. Nature Reviews Cardiology, 15(4), 230-240. https://doi.org/10.1038/nrcardio.2017.154

Arocha Rodulfo, J. I. (2019). Sedentarism, a disease from xxi century. Clínica e Investigación En Arteriosclerosis (English Edition), 31(5), 233-240. https://doi.org/10.1016/j.artere.2019.04.001

Baecke, J. A. H., Burema, J., \& Frijters, J. E. R. (1982). A short questionnaire for the measurement of habitual physical activity in epidemiological studies. American Journal of Clinical Nutrition, 36(5), 936-942. https://doi.org/10.1093/ajcn/36.5.936

Beck, A. T., Ward, C. H., Mendelson, M., Mock, J., \& Erbaugh, J. (1961). An Inventory for Measuring Depression The difficulties inherent in obtaining. Archives of General Psychiatry, 4, 561-571.

Beiter, R., Nash, R., McCrady, M., Rhoades, D., Linscomb, M., Clarahan, M., \& Sammut, S. (2015). The prevalence and correlates of depression, anxiety, and stress in a sample of college students. Journal of Affective Disorders, 173, 90-96. https://doi.org/10.1016/j.jad.2014.10.054 
Bhatti, S. N., Leidi, A., Leake, D., \& Li, J. M. (2020). Studying biological science does not lead to adoption of a healthy lifestyle. Perspectives in Public Health, 140(4), 232-239. https://doi.org/10.1177/1757913919890889

Biaggio, A. M., Natalício, L., \& Spielberger, C. (1977). Desenvolvimento da forma experimental em português do Inventário de Ansiedade Traço-Estado (IDATE), de Spielberger. Arquivos Brasileiros de Psicologia Aplicada, 29(3), 31-44.

Bueno, H. M. P., Sartori, M., Macedo, H. R., Moraes-Silva, I. C., Aletti, F., Irigoyen, M. C., \& De Angelis, K. (2017). Bicycling for transportation improves heart rate variability in young adults. Journal of Sports Medicine and Physical Fitness, 57(3), 299-304. https://doi.org/10.23736/S0022-4707.16.06037-0

Caspersen, C. J., Powell, K. E., \& Christenson, G. M. (1985). Physical activity, exercise, and physical fitness: definitions and distinctions for health-related research. Public Health Reports, 100(2), 126-131.

Chaplin, A. B., Rebecca, Z., Golam, M., Daniels, N. F., \& Ples, D. (2021). Longitudinal association between cardiovascular risk factors and depression in young people: a systematic review and meta-analysis of cohort studies.

Concha-Cisternas, Y., Guzmán-Muñoz, E., Valdés-Badilla, P., Lira-Cea, C., Petermann, F., \& Celis-Morales, C. (2018). Factores de riesgo asociados a bajo nivel de actividad física y exceso de peso corporal en estudiantes universitarios. Revista Médica de Chile, 146(8), 840-849. https://doi.org/10.4067/s003498872018000800840

Doerr, J. M., Ditzen, B., Strahler, J., Linnemann, A., Ziemek, J., Skoluda, N., Hoppmann, C. A., \& Nater, U. M. (2015). Reciprocal relationship between acute stress and acute fatigue in everyday life in a sample of university students. Biological Psychology, 110, 42-49. https://doi.org/10.1016/j.biopsycho.2015.06.009

Engin, A. (2017). The Definition and Prevalence of Obesity and Metabolic Syndrome. Obesity and Lipotoxicity, 960, 1-17. https://doi.org/10.1007/978-3-319$48382-5$

Fan, L. M., Fan, L. M., Collins, A., Geng, L., Geng, L., Li, J. M., \& Li, J. M. (2020). Impact of unhealthy lifestyle on cardiorespiratory fitness and heart rate recovery of medical science students. BMC Public Health, 20(1), 4-11. https://doi.org/10.1186/s12889-020-09154-x

Ferrati, T. A. (1982). Metodologia da pesquisa científica. São Paulo: McGraw-Hil.

Fórum Nacional de Pró-reitores de Assuntos Estudantis. (2016). IV pesquisa do perfil socioeconômico dos estudantes de graduação das universidades federais. Andifes. http://www.andifes.org.br/wp-content/uploads/2017/11/Pesquisa-de-Perfil-dos-Graduanso-das-IFES_2014.pdf

Gaviria, H. A. M., Blandón, D. A. S., Durango, M. del P. P., \& Yepes, T. A. (2017). Overweight and obesity conditions: Prevalence and associated risk factors in nursing students in a public university in Medellín, Colombia. Investigacion y Educacion En Enfermeria, 35(2), 191-198. https://doi.org/10.17533/udea.iee.v35n2a08

Gorestein, C., \& ANDRANDE, L. (1998). Inventário de depressão de Beck : propriedades psicométricas da versão em português. Revista de Psiquiatria Clínica, $25(5), 245-250$.

Guazzi, M., Adams, V., Conraads, V., Halle, M., Mezzani, A., Vanhees, L., Arena, R., Fletcher, G. F., Forman, D. E., Kitzman, D. W., Lavie, C. J., \& Myers, J. (2012). Clinical recommendations for cardiopulmonary exercise testing data assessment in specific patient populations. European Heart Journal, 33(23), 29172927. https://doi.org/10.1093/eurheartj/ehs221

Harmouche-Karaki, M., Mahfouz, M., Mahfouz, Y., Fakhoury-Sayegh, N., \& Helou, K. (2020). Combined effect of physical activity and sedentary behavior on body composition in university students. Clinical Nutrition, 39(5), 1517-1524. https://doi.org/10.1016/j.clnu.2019.06.015

Harvey, S. B., Overland, S., Hatch, S. L., Wessely, S., Mykletun, A., \& Hotopf, M. (2018). Exercise and the prevention of depression: Results of the HUNT cohort study. American Journal of Psychiatry, 175(1), 28-36. https://doi.org/10.1176/appi.ajp.2017.16111223

Hillebrand, S., Gast, K. B., De Mutsert, R., Swenne, C. A., Jukema, J. W., Middeldorp, S., Rosendaal, F. R., \& Dekkers, O. M. (2013). Heart rate variability and first cardiovascular event in populations without known cardiovascular disease: Meta-analysis and dose-response meta-regression. Europace, 15(5), 742-749. https://doi.org/10.1093/europace/eus341

Ibrahim, A. K., Kelly, S. J., Adams, C. E., \& Glazebrook, C. (2013). A systematic review of studies of depression prevalence in university students. Journal of Psychiatric Research, 47(3), 391-400. https://doi.org/10.1016/j.jpsychires.2012.11.015

Ignacio, O.-G., Margarita, F.-L. R., Amado, I. R. S., \& Erasmo, C. A. C. (2019). Presión Arterial Elevada Y Otros Factores De Riesgo Cardiovascular En Estudiantes De La Universidad Nacional De Asunción-Paraguay. Revista de La Facultad de Ciencias Médicas de Córdoba, 76(2), 79-85. https://revistas.unc.edu.ar/index.php/med/article/view/23152

Instituto Brasileiro de Geografia e Estatística. (2020). Pesquisa nacional de saúde : 2019 : percepção do estado de saúde, estilos de vida, doenças crônicas e saúde bucal : Brasil e grandes regiões. 113.

Jackson, A. S., \& Pollock, M. L. (1978). Generalized equations for predicting body density of men. British Journal of Nutrition, 40(3), 497-504. https://doi.org/10.1079/bjn19780152

Jackson, Andrew S, Pollock, M. L., \& Ward, A. (1980). Generalized equations for predicting body density of women. MEDICINE AND SCIENCE IN SPORTS AND EXERCISE, 12(3), 175-182.

Jiang, Y., Wang, J., Wu, S., Li, N., Wang, Y., Liu, J., Xu, X., He, Z., Cheng, Y., Zeng, X., Wang, B., Zhang, C., Zhao, M., Su, Z., Guo, B., Yang, W., \& Zheng, R. (2019). Association between take-out food consumption and obesity among chinese university students: A cross-sectional study. International Journal of Environmental Research and Public Health, 16(6). https://doi.org/10.3390/ijerph16061071

Kingsley, J. D., \& Figueroa, A. (2016). Acute and training effects of resistance exercise on heart rate variability. Clinical Physiology and Functional Imaging, 36(3), 179-187. https://doi.org/10.1111/cpf.12223 
Kiviniemi, A. M., Tulppo, M. P., Eskelinen, J. J., Savolainen, A. M., Kapanen, J., Heinonen, I. H. A., Huikuri, H. V., Hannukainen, J. C., \& Kalliokoski, K. K. (2014). Cardiac autonomic function and high-intensity interval training in middle-age men. Medicine and Science in Sports and Exercise, 46(10), 1960-1967. https://doi.org/10.1249/MSS.0000000000000307

Kvam, S., Kleppe, C. L., Nordhus, I. H., \& Hovland, A. (2016). Exercise as a treatment for depression: A meta-analysis. Journal of Affective Disorders, 202, 67-86. https://doi.org/10.1016/j.jad.2016.03.06

Lee, E., \& Kim, Y. (2019). Effect of university students' sedentary behavior on stress, anxiety, and depression. Perspectives in Psychiatric Care, 55(2), 164169. https://doi.org/10.1111/ppc. 12296

Lew, B., Huen, J., Yu, P., Yuan, L., Wang, D. F., Ping, F., Talib, M. A., Lester, D., \& Jia, C. X. (2019). Associations between depression, anxiety, stress, hopelessness, subjective well-being, coping styles and suicide in Chinese university students. PLoS ONE, 14(7), 1-10. https://doi.org/10.1371/journal.pone.0217372

Lun, K. W. C., Chan, C. K., Ip, P. K. Y., Ma, S. Y. K., Tsai, W. W., Wong, C. S., Wong, C. H. T., Wong, T. W., \& Yan, D. (2018). Depression and anxiety among university students in Hong Kong. Hong Kong Medical Journal, 24(5), 466-472. https://doi.org/10.12809/hkmj176915

Maillard, F., Pereira, B., \& Boisseau, N. (2018). Effect of High-Intensity Interval Training on Total, Abdominal and Visceral Fat Mass: A Meta-Analysis. Sports Medicine, 48(2), 269-288. https://doi.org/10.1007/s40279-017-0807-y

Mandsager, K., Harb, S., Cremer, P., Phelan, D., Nissen, S. E., \& Jaber, W. (2018). Association of Cardiorespiratory Fitness With Long-term Mortality Among Adults Undergoing Exercise Treadmill Testing. JAMA Network Open, 1(6), e183605. https://doi.org/10.1001/jamanetworkopen.2018.3605

Marães, V. R. F. S. (2010). Frequência cardíaca e sua variabilidade: análises e aplicações. Rev Andal Med Deporte, 3(1), 33-42. https://doi.org/10.36104/amc.2018.1400

Marker, A. M., Steele, R. G., \& Noser, A. E. (2018). Physical activity and health-related quality of life in children and adolescents: A systematic review and meta-analysis. Health Psychology, 37(10), 893-903. https://doi.org/10.1037/hea0000653

Marques, A., Santos, D. A., Hillman, C. H., \& Sardinha, L. B. (2018). How does academic achievement relate to cardiorespiratory fitness, self-reported physical activity and objectively reported physical activity: A systematic review in children and adolescents aged 6-18 years. British Journal of Sports Medicine, 52(16), 1039. https://doi.org/10.1136/bjsports-2016-097361

Meyer, J. D., Koltyn, K. F., Stegner, A. J., Kim, J. S., \& Cook, D. B. (2016). Influence of Exercise Intensity for Improving Depressed Mood in Depression: A Dose-Response Study. Behavior Therapy, 47(4), 527-537. https://doi.org/10.1016/j.beth.2016.04.003

Minatel, V., Karsten, M., Neves, L. M. T., Beltrame, T., Borghi-Silva, A., \& Catai, A. M. (2012). Avaliação da frequência cardíaca à medida de pressão expiratória máxima estática e à manobra de Valsalva em jovens saudáveis. Brazilian Journal of Physical Therapy, 16(5), 406-413. https://doi.org/10.1590/S1413-35552012005000045

Molina, G. E., Fontana, K. E., Porto, L. G. G., \& Junqueira, L. F. (2016). Post-exercise heart-rate recovery correlates to resting heart-rate variability in healthy men. Clinical Autonomic Research, 26(6), 415-421. https://doi.org/10.1007/s10286-016-0378-2

Mondal, H., \& Mishra, S. P. (2017). Effect of BMI, body fat percentage and fat free mass on maximal oxygen consumption in healthy young adults. Journal of Clinical and Diagnostic Research, 11(6), CC17-CC20. https://doi.org/10.7860/JCDR/2017/25465.10039

Moraes, Í. A. P., Silva, T. D., Massetti, T., Menezes, L. D. C., Ribeiro, V. F., Tropiano, L. M. C. C., Barnabé, V., Hoshi, R. A., Monteiro, C. B. M., \& Fernandes, M. (2019). Fractal correlations and linear analyses of heart rate variability in healthy young people with different levels of physical activity. https://doi.org/10.1017/S1047951119001793

Mota, D. D. C. F., Pimenta, C. A. M., \& Piper, B. F. (2009). Fatigue in Brazilian cancer patients, caregivers, and nursing students: A psychometric validation study of the Piper Fatigue Scale-Revised. Supportive Care in Cancer, 17(6), 645-652. https://doi.org/10.1007/s00520-008-0518-x

Oberoi, S., Robinson, P. D., Cataudella, D., Culos-Reed, S. N., Davis, H., Duong, N., Gibson, F., Götte, M., Hinds, P., Nijhof, S. L., Tomlinson, D., van der Torre, P., Cabral, S., Dupuis, L. L., \& Sung, L. (2018). Physical activity reduces fatigue in patients with cancer and hematopoietic stem cell transplant recipients: A systematic review and meta-analysis of randomized trials. Critical Reviews in Oncology/Hematology, 122(December 2017), 52-59. https://doi.org/10.1016/j.critrevonc.2017.12.011

Osimo, E. F., Baxter, L. J., Lewis, G., Jones, P. B., \& Khandaker, G. M. (2019). Prevalence of low-grade inflammation in depression: A systematic review and meta-Analysis of CRP levels. Psychological Medicine, 49(12), 1958-1970. https://doi.org/10.1017/S0033291719001454

Ozemek, C., Laddu, D. R., Lavie, C. J., Claeys, H., Kaminsky, L. A., Ross, R., Wisloff, U., Arena, R., \& Blair, S. N. (2018). An Update on the Role of Cardiorespiratory Fitness, Structured Exercise and Lifestyle Physical Activity in Preventing Cardiovascular Disease and Health Risk. Progress in Cardiovascular Diseases, 61(5-6), 484-490. https://doi.org/10.1016/j.pcad.2018.11.005

Paulitsch, R. G., Dumith, S. C., \& Susin, L. R. O. (2017). Simultaneidade de fatores de risco comportamentais para doença cardiovascular em estudantes universitários. Revista Brasileira de Epidemiologia, 20(4), 624-635. https://doi.org/10.1590/1980-5497201700040006

Quek, T. T. C., Tam, W. W. S., Tran, B. X., Zhang, M., Zhang, Z., Ho, C. S. H., \& Ho, R. C. M. (2019). Labrague, L. J., McEnroe-Petitte, D. M., Gloe, D., Thomas, L., Papathanasiou, I. V, \& Tsaras, K. (2017). A literature review on stress and coping strategies in nursing students. Journal of Mental Health, 26(5), 471-480. https://doi.org/10.1080/09638237.20. International Journal of Environmental Research and Public Health, 16(15), 2735. https://www.mdpi.com/1660-4601/16/15/2735

Ramón-Arbués, E., Gea-Caballero, V., Granada-López, J. M., Juárez-Vela, R., Pellicer-García, B., \& Antón-Solanas, I. (2020). The prevalence of depression, anxiety and stress and their associated factors in college students. International Journal of Environmental Research and Public Health, 17(19), 1-15. https://doi.org/10.3390/ijerph17197001 
Schorr, M., Dichtel, L. E., Gerweck, A. V., Valera, R. D., Torriani, M., Miller, K. K., \& Bredella, M. A. (2018). Sex differences in body composition and association with cardiometabolic risk. Biology of Sex Differences, 9(1), 1-10. https://doi.org/10.1186/s13293-018-0189-3

Silva, F. M., Petrica, J., Serrano, J., Paulo, R., Ramalho, A., Lucas, D., Ferreira, J. P., \& Duarte-Mendes, P. (2019). The sedentary time and physical activity levels on physical fitness in the elderly: A comparative cross sectional study. International Journal of Environmental Research and Public Health, 16(19), 111. https://doi.org/10.3390/ijerph16193697

Silva, O. B. e. (2014). Velocidade e Inclinação da Esteira Ergométrica no Protocolo em Rampa. Revista DERC, 20(1), 10-11.

Singh, V., Gupta, A., Sohal, J. S., \& Singh, A. (2019). A unified non-linear approach based on recurrence quantification analysis and approximate entropy: application to the classification of heart rate variability of age-stratified subjects. Medical and Biological Engineering and Computing, 57(3), 741-755. https://doi.org/10.1007/s11517-018-1914-0

Siri, W. E. (1961). Body composition from fluid spaces and density: analysis of methods. National Research Council, $223-244$.

Spielberger, C. D., Gorsuch, R. L., \& Lushene, R. E. (1970). Manual for the State-Trait Anxiety Inventory. Consulting Psychologists Press.

Stavrinou, P. S., Bogdanis, G. C., Giannaki, C. D., Terzis, G., \& Hadjicharalambous, M. (2018). High-intensity Interval Training Frequency: Cardiometabolic Effects and Quality of Life. International Journal of Sports Medicine, 39(3), 210-217. https://doi.org/10.1055/s-0043-125074

Stonerock, G. L., Hoffman, B. M., Smith, P. J., \& Blumenthal, J. A. (2015). Exercise as Treatment for Anxiety: Systematic Review and Analysis. Annals of Behavioral Medicine, 49(4), 542-556. https://doi.org/10.1007/s12160-014-9685-9.Exercise

Task Force of the European Society of Cardiology and the North American Society of Pacing and Electrophysiology. (1996). Heart Rate Variability: standards of measurements, physiological interpretation and clinical use. Circulation, 93, 1043-1065.

Teychenne, M., Costigan, S. A., \& Parker, K. (2015). The association between sedentary behaviour and risk of anxiety: A systematic review Health behavior, health promotion and society. BMC Public Health, 15(1). https://doi.org/10.1186/s12889-015-1843-x

Tornberg, J., Ikäheimo, T. M., Kiviniemi, A., Pyky, R., Hautala, A., Mäntysaari, M., Jämsä, T., \& Korpelainen, R. (2019). Phy sical activity is associated with cardiac autonomic function in adolescent men. PLOS ONE, 14(9), 1-10. https://doi.org/10.1371/journal.pone.0222121

Tremblay, M. S., Aubert, S., Barnes, J. D., Saunders, T. J., Carson, V., Latimer-Cheung, A. E., Chastin, S. F. M., Altenburg, T. M., Chinapaw, M. J. M., Aminian, S., Arundell, L., Hinkley, T., Hnatiuk, J., Atkin, A. J., Belanger, K., Chaput, J. P., Gunnell, K., Larouche, R., Manyanga, T., ... Wondergem, R. (2017). Sedentary Behavior Research Network (SBRN) - Terminology Consensus Project process and outcome. International Journal of Behavioral Nutrition and Physical Activity, 14(1), 1-17. https://doi.org/10.1186/s12966-017-0525-8

Tung, Y. J., Lo, K. K. H., Ho, R. C. M., \& Tam, W. S. W. (2018). Prevalence of depression among nursing students: A systematic review and meta-analysis. Nurse Education Today, 63(January), 119-129. https://doi.org/10.1016/j.nedt.2018.01.009

Viana, R. B., Gentil, P., Naves, J. P. A., Rebelo, A. C. S., Santos, D. A. T., Braga, M. A. O., \& de Lira, C. A. B. (2019). Interval Training Improves Depressive Symptoms But Not Anxious Symptoms in Healthy Women. Frontiers in Psychiatry, 10(September), 1-8. https://doi.org/10.3389/fpsyt.2019.00661

WARE, J. E., \& SHERBOUERNE, C. . (1992). The MOS 36-item short-form health survey (SF-36). I. Conceptual framework and item selection. Medical Care, $30(6), 473-483$.

WHO Guidelines on physical activity and sedentary behaviour, World Health Organization 104 (2020). https://apps.who.int/iris/bitstream/handle/10665/325147/WHO-NMH-PND-2019.4-

eng.pdf?sequence=1\&isAllowed=y\%0Ahttp://www.who.int/iris/handle/10665/311664\%0Ahttps://apps.who.int/iris/handle/10665/325147

Depression and Other Common Mental Disorders, Geneva: World Health Organization (2017).

World Health Organization (WHO). (2021). Suicide worldwide in 2019: global health estimates.

Younes, F., Halawi, G., Jabbour, H., Osta, N. El, Karam, L., Hajj, A., \& Khabbaz, L. R. (2016). Internet addiction and relationships with insomnia, anxiety, depression, stress and self-esteem in university students: A cross-sectional designed study. PLoS ONE, 11(9), 1-13. https://doi.org/10.1371/journal.pone.0161126

Zuttin, R., Moreno, M., César, M., Martins, L., Catai, A., \& Silva, E. (2008). Avaliação da modulação autonômica da freqüência cardíaca nas posturas supina e sentada de homens jovens sedentários. Revista Brasileira de Fisioterapia, 12(1), 7-12. https://doi.org/10.1590/s1413-35552008000100003 